\title{
Medievalista
}

Online

$24 \mid 2018$

Número 24

\section{Growing presence of the IEM at the International Congress on Medieval Studies (Kalamazoo, Michigan)}

\section{Alícia Miguélez}

\section{OpenEdition}

\section{Journals}

Edição electrónica

URL: http://journals.openedition.org/medievalista/1713

DOI: 10.4000/medievalista. 1713

ISSN: 1646-740X

Editora

Instituto de Estudos Medievais - FCSH-UNL

\section{Refêrencia eletrónica}

Alícia Miguélez, «Growing presence of the IEM at the International Congress on Medieval Studies (Kalamazoo, Michigan) », Medievalista [Online], 24 | 2018, posto online no dia 16 março 2019,

consultado o 23 setembro 2020. URL : http://journals.openedition.org/medievalista/1713 ; DOI https://doi.org/10.4000/medievalista.1713

\section{Este documento foi criado de forma automática no dia 23 setembro 2020.}

\section{(c) (7) \&)}

Mediavalista está licenciado com uma Licença Creative Commons - Atribuição-NãoComercial 4.0 Internacional. 


\title{
Growing presence of the IEM at the International Congress on Medieval Studies (Kalamazoo, Michigan)
}

\author{
Alícia Miguélez
}

\section{NOTA DO EDITOR}

Data recepção do artigo / Received for publication: 26-05-2018

1 The International Congress on Medieval Studies, which takes place every year at the Western Michigan University (Kalamazoo, MI, USA), is hosted by the Medieval Institute and brings together around 3,000 researchers and experts in Medieval Studies. This is by far the oldest annual scientific meeting devoted to the study of the Middle Ages and, along with the International Medieval Congress of the University of Leeds (UK) and the International Medieval Meeting of the University of Lleida (Spain), a worldwide reference for any scholar, research center, academic institution or publishing house with any kind of relationship or interest on medieval studies. The 53th edition of this conference took place on May 10-13, 2018 and reached the number of 552 sessions and 232 sponsoring organizations.

2 The IEM, as the only Portuguese research center exclusively devoted to the study of the Middle Ages, has experienced a growing presence at this conference. First through personal participation and, since 2017, through the organization and sponsorship of sessions, the active participation of the IEM at the Kalamazoo's conference reveals its increasing level of internationalization and global impact within the field of Medieval Studies. Furthermore, by initiative of the IEM, the presence of Portuguese medievalists and/or Portuguese and Iberian Medieval History and heritage has grown in the conference program in the past recent years.

In the 2018 edition, up to four sessions were co-organized by the Institute in collaboration with two other Portuguese research centers, the Centro de História (CH) of 
the Universidade de Lisboa and the Centro de Estudos de Sociologia e Estetica Medieval (CESEM) of the NOVA FCSH. Session 363, co-sponsored by the IEM and the Centro de História, organized by Maria João Branco (NOVA FCSH) and Hermenegildo Fernandes ( $\mathrm{CH}$ ULisboa) and presided by Kyle C. Lincoln (Kalamazoo College), was devoted to "Diplomacy in Medieval Iberia: Language, Men and Texts in Diplomatic Exchanges (Twelfth-Fourteenth Centuries)". Three papers were delivered within this session: Maria João Branco talked on "Papal Judges Delegates as Diplomats in Twelfth-Century Portugal: Profiling a Difficult Function in a Conflictive Millieux"; Hermenegildo Fernandes ( $\mathrm{CH}$, ULisboa) contributed to this session with a paper on the topic "Negotiating Peace in a Western Islamic Frontier: The Almohads Face to Face with the Portuguese Kingdom (1212-1230)". On her part, Covadonga Valdaliso ( $\mathrm{CH}$, ULisboa) delivered a paper on "Another Form of Diplomacy? Rituals in the Portuguese-Castilian Frontier in the Late Middle Ages".

4 Sessions 444 and 445, co-sponsored by the IEM and the Centro de Estudos de Sociologia e Estética Musical (CESEM, NOVA FCSH), and organized by Elsa De Luca (CESEM, NOVA FCSH) and Alicia Miguélez (IEM, NOVA FCSH) were devoted to the topic "Medieval Iberian Cultural Identity: the Manuscript Record". The subject was investigated as seen through the lenses of the surviving Iberian-related manuscripts, including both those produced in the Iberian Peninsula and those arrived from elsewhere but which became, at a certain point, part of the Iberian intellectual history. Moreover, the two proposed sessions had an interdisciplinary soul since manuscripts were investigated from a broad perspective: historical milieu, music, decoration, liturgy, use(s), literary contents etc. And these two sessions involved the participation of scholars coming from different backgrounds and academic institutions, all of them working on Medieval Iberia. Two musicologists delivered papers on musical manuscripts: Rui Araújo (CESEM, NOVA FCSH) on "Musical Continuities between the Cantigas de Santa Maria and the Cancionero Musical de Palacio (MS-II-1335)", and Nuria Torres (Univ. Complutense, Madrid) on "What the Fragments Are Hiding: Connections between the Polyphonic Fragments Preserved in Castile and the Manuscripts of Notre Dame". Alicia Miguélez (IEM, NOVA FCSH) contributed with a study on the political uses of medieval illuminated manuscripts under the title "Visual Models in Motion in Medieval Iberia". Two more papers dealt with medieval bibles, Matthias Tischler working on "The Bible in a Fragmentary World Constructing Medieval Ibery Identity through the Christians' Most Venerable Legacy" and Mieko Kezuka (Kyoristu Women's Univ.) on "Trial of Reading Symbols: An Iconographic Study of the Canon Tables of León Bible of 960". Finally, Stefanos Kroustallis (Escuela Superior de Conservación y Restauración de Bienes Culturales, Madrid) contributed with a paper dealing with "The Transmission of Art Technology in Medieval Spain: From the Mappae clavicula Treatise of the Ms. 19 BNE (Twelfth Century) to the Recipe Book of Joanot Valero (Fifteenth Century)".

The 53th edition of the International Congress on Medieval Studies turned thus into the edition in which the IEM has played the most important role so far. The active participation and the vigorous debate prompted by the audience in the three sessions leads to consider that the ideas and hypotheses presented by scholars had a warm welcome and that the topics approached rouse the interest of scholars working on Medieval Iberia. It is to be expected that IEM's presence at this annual meeting might still grow in the years to come. 


\section{AUTOR}

\section{ALÍCIA MIGUÉLEZ}

Universidade Nova de Lisboa, Faculdade de Ciências Sociais e Humanas, Instituto de Estudos Medievais, 1069-061, Lisboa, Portugal

amiguelez@fcsh.unl.pt 